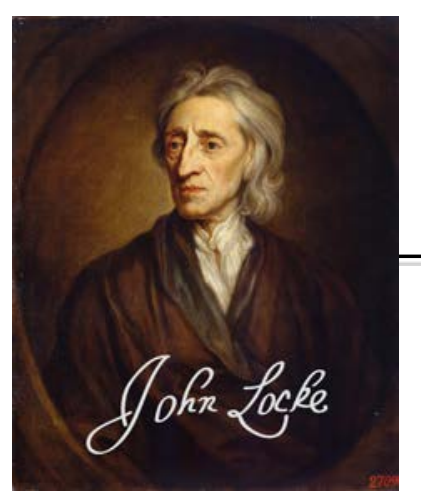

LOCKE STUDIES

Vol. 20

https://doi.org/10.5206/ls.2020.10799 | ISSN: 2561-925X

Submitted: 19 JUNE 2020

Revised: 03 NOVEMBER 2020

Published online: 15 JANUARY 2021

For more information, see this article's homepage.

(c) 2021. Nathan Rockwood

\title{
Secondary Qualities as Dispositions
}

\author{
NATHAN ROCKWOOD (BRIGHAM YOUNG UNIVERSITY)
}

\begin{abstract}
:
In this paper I will defend the view that, according to Locke, secondary qualities are dispositions to produce sensations in us. Although this view is widely attributed to Locke, this interpretation needs defending for two reasons. First, commentators often assume that secondary qualities are dispositional properties because Locke calls them "powers" to produce sensations. However, primary qualities are also powers, so the powers locution is insufficient grounds for justifying the dispositionalist interpretation. Second, if secondary qualities are dispositional properties, then objects would retain secondary qualities while not being observed, but Locke says that colors "vanish" in the dark. Some commentators use this as evidence that Locke rejects the dispositionalist view of secondary qualities, and even those that are sympathetic to the traditional interpretation find these comments to be problematic. By contrast, I argue that even in these supposedly damning passages Locke shows an unwavering commitment to the view that the powers to produce sensations in us, i.e., the secondary qualities, remain in objects even when they are not being perceived. Thus, the arguments against the traditional interpretation are unpersuasive, and we should conclude that Locke does indeed hold that secondary qualities are dispositions to cause sensations in us.
\end{abstract}

Keywords: J ohn Locke, primary qualities, secondary qualities, powers, metaphysics, dispositions, color

Locke Studies is published by The John Locke Society.

This is an open access article published under the terms of the Creative Commons AttributionNonCommercial-ShareAlike 4.0 International license, which permits use, distribution and reproduction in any medium, provided the original work is properly cited and shared under the original license. 


\section{A Challenge}

One of Locke's lasting contributions to metaphysics is his distinction between primary and secondary qualities. Yet how exactly to understand Locke's distinction remains controversial. Traditionally, Locke has been interpreted as holding that secondary qualities, such as color, are dispositional properties. An important feature of a dispositional property is that an object retains that property even when its defining characteristic is not manifest. So, for example, the defining characteristic of red is that it appears a certain way to normal observers in standard conditions, and if red is a dispositional property, then an object can be red even when it does not currently appear red. However, Locke says that an object's colors "vanish" in the dark (II.viii.19, 139). ${ }^{1}$ Recent commentators have used this as evidence that Locke does not accept that secondary qualities are dispositional properties after all, $^{2}$ and even those who do accept the traditional interpretation concede that this sort of comment is inconsistent with his official position. ${ }^{3}$ By contrast, below I will argue that these supposedly problematic passages actually entail a commitment to the dispositionalist account of secondary qualities.

Call the view that secondary qualities are dispositions the Dispositionalist View. Here is an overly simplistic argument that is often used to show that Locke holds this sort of view: Locke defines secondary qualities as powers; powers are dispositions; and so secondary qualities are dispositions. ${ }^{4}$ But this argument does not work. Primary qualities are also powers (II.viii.8, 134- 35) ${ }^{5}$ and primary qualities are categorical not dispositional properties. Thus, it does not follow from the fact that secondary qualities are powers that they are dispositions. So, if metaphysicians and historians of philosophy are going to continue to attribute the Dispositionalist View to Locke, then a better argument is needed, and the objections to this interpretation need to be answered.

${ }^{1}$ All references to Locke's Essay are to the Nidditch edition: J ohn Locke, An Essay concerning Human Understanding, ed. Peter H. Nidditch, The Clarendon Edition of the Works of J ohn Locke (Oxford: Clarendon Press, 1975).

2 Samuel C. Rickless, "Locke on Primary and Secondary Qualities," Pacific Philosophical Quarterly 78, no. 3 (September 1997): 297- 319; Matthew Stuart, "Locke's Colors," The Philosophical Review 112, no. 1 (J anuary 2003): 57-96, https:// www.doi.org/10.1215/00318108-112-1-57; Robert Pasnau, Metaphysical Themes, 1274- 1671 (Oxford: Clarendon Press, 2011).

${ }^{3}$ Edwin M. Curley, "Locke, Boyle, and the Distinction between Primary and Secondary Qualities," The Philosophical Review 81, no. 4 (October 1972): 438-64, https:// www.doi.org/ 10.2307/2183887; E. J. Lowe, Locke on Human Understanding, Routledge Philosophy Guidebooks (New York: Routledge, 1995).

4 Lowe, Locke on Human Understanding; J onathan Bennett, Locke, Berkeley, Hume: Central Themes (Oxford: Clarendon Press, 1971).

${ }^{5}$ Some commentators claim that Locke does not take primary qualities to be powers because, they argue, this would collapse his distinction between primary and secondary qualities. I respond to this claim below. 
Fortunately, there is a better reason for attributing the Dispositionalist View. On the one hand, Locke defines secondary qualities in terms of the sensations they cause in us. (Although primary qualities also cause sensations in us, primary qualities are not defined by these sensations.) An object is red, for example, if it appears a certain way to us. On the other hand, objects with secondary qualities are not always causing us to have these sensations. As a result, the defining characteristic of secondary qualities is manifest only when certain conditions are met. Lockeinsists that objects retain their secondary qualities even when not being perceived; indeed, I will argue that the real essences of objects guarantee that objects must retain their secondary qualities while not being perceived. Since objects have secondary qualities even when the defining characteristic of those qualities is not manifest, Locke appears to be taking secondary qualities as dispositional properties. Thus, Locke seems to accept the Dispositionalist View.

\section{Dispositional Properties}

In contemporary metaphysics, categorical properties are distinguished from dispositional properties, and according to the Dispositionalist View, Locke's primary qualities are categorical properties whereas secondary qualities are dispositional properties. The connection between Locke's view and contemporary metaphysics is not coincidental. The primary qualities of size, shape, and motion are often cited as paradigmatic examples of categorical properties ${ }^{6}$ and Locke is often cited as an early and influential proponent of the view that secondary qualities are dispositional properties. ${ }^{7}$ Even if the Dispositionalist View is not the correct interpretation of Locke, this interpretation has had significant influence on later developments in metaphysics. The goal of this section is to explicate the distinction between categorical and dispositional properties and briefly explain why Locke has often been interpreted as holding that primary qualities are categorical properties while secondary qualities are dispositional properties.

Dispositional properties are conditional in a way that categorical properties are not. ${ }^{8}$ Properties each have a distinguishing characteristic. For dispositional properties, the distinguishing characteristic is manifest only when certain conditions are met. For example, the defining characteristic of fragility is easily breaking, and so, to say a glass vase is fragile indicates that under certain conditions the vase will break (such as when it is struck). Yet the glass vase is currently fragile even if it is not now breaking. So, the defining characteristic of fragility (easily breaking), in some way, remains hidden, existing only as a potentiality, and hence the property is not "manifest." The vase is now is fragile, even though it is not breaking. An object can have a dispositional property without

${ }^{6}$ Stephen Mumford, Dispositions, revised edition (Oxford: Clarendon Press, 2003), 4- 5 and 150- 51.

${ }^{7}$ Mark J ohnston, "How to Speak of the Colors," Philosophical Studies: An International J ournal for Philosophy in the Analytic Tradition 68, no. 3 (December 1992): 221- 63.

8 Mumford, Dispositions, 87-90. 
manifesting this property, and the defining characteristic of the property is manifest only under certain conditions.

By contrast, categorical properties are not conditional in this way. The defining characteristic of being round is having every point of its surface equidistant from the center. If an object does not currently exhibit this defining characteristic of being round, then the object simply is not round. To be sure, there are some merely conditional properties of a circle: for example, if a circular is placed on an incline it will roll down the hill. But this conditional characteristic of a circle is not the defining characteristic of circularity; the object is fully manifesting its circularity (what makes it a circle) even if some other features of a circle are not currently manifest. Circularity then differs from fragility and other dispositional properties. For the dispositional property of fragility manifests its defining characteristic only under certain conditions, whereas this is not true of categorical properties.

While most primary qualities (such as size, shape, and motion) fall squarely in the category of categorical properties, it is much less clear that solidity is a categorical property. For solidity might be understood as impenetrability and impenetrability might be thought of as a dispositional property: impenetrability "describes how an object will act in certain circumstances when it collides with another body of its own kind, not what it is in itself." 9 However, Locke does not think of solidity in this way: he says impenetrability is "more a consequence of solidity, than solidity itself" (II.iv.1, 123; my emphasis). Instead, Locke thinks of solidity as occupied space. In a section titled "Solidity fills Space" Locke says that the idea of solidity "belongs to Body, whereby we conceive it to fill space" (II.iv.2, 123). On this description, the defining characteristic of solidity is "all-or-nothing," 10 making solidity a categorical property. ${ }^{11}$ Thus, for Locke, it appears that all primary qualities are categorical properties.

One common position in contemporary metaphysics is that the secondary qualities of color and sound are dispositional properties. For example, the defining characteristic of red is appearing a certain way; that is, an object is red if it looks red under standard conditions. Yet a red object does not always look red. It only looks red under certain conditions. From these considerations (if correct) it follows that an object can be red without manifesting its defining characteristic, and that it will manifest its defining characteristic only when certain conditions are met. This would make the property red a dispositional property.

Further, there is some reason to believe that Locke thinks of colors (and other secondary qualities) in this way. Locke says, for example, "Yellowness is not actually in Gold; but is a Power in Gold, to produce that Idea in us by our Eyes, when placed in a due Light" (II.xxiii.10, 301). A yellow object does not always appear yellow; but it does appear yellow "when placed in due Light." The defining characteristic of yellow, then, is manifest

\footnotetext{
${ }^{9}$ Mumford, Dispositions, 31.

10 Matthew Stuart, Locke's Metaphysics (Oxford: Clarendon Press, 2013), 57.

${ }^{11}$ For more discussion on Locke’s account of solidity, see Stuart, Locke's Metaphysics, 55- 65.
} 
only conditionally. Yet there is a "Power in Gold" to produce the sensation of yellow that, presumably, remains in the object even when it is not currently causing in us the sensation of yellow. (I defend this claim below.) The secondary quality yellow, then, appears to be a dispositional property.

Sometimes it is claimed that secondary qualities are powers whereas primary qualities are not. In contemporary metaphysics "causal power" often refers to dispositional properties, and some have (erroneously) argued that because Locke takes secondary qualities as powers, they must be dispositional properties. ${ }^{12}$ But this is too quick because Locke also calls primary qualities powers (II.viii.8, 134) and (as argued above) primary qualities are categorical properties. Some commentators, though, dismiss Locke's description of primary qualities as powers because, if that were so, they think that this would collapse the distinction between primary and secondary qualities. ${ }^{13}$

I think that Locke can maintain a substantive metaphysical distinction between primary and secondary qualities even though he takes them both to be powers. Locke says, "the Power to produce any Idea in our mind, I call Quality" (II.viii.8, 134). This comment alone is enough to warrant an interpretation that makes primary quality a power, but the context provides even more evidence. Hetitles the following sections "How primary Qualities produce their Ideas" (i.e., ideas of primary qualities) (II.viii.11- 12, 135- 36) and then "How Secondary" (II.viii.13- 14, 136- 37). So, Locke describes primary qualities as a power to produce ideas. Yet this description of primary qualities is so deficient that it might not represent Locke's considered view. Is being circular merely a property to cause in us ideas? Surely if there were a circular object in the world, but no minds, the object would still be circular. The ability of the object to cause in us the idea of a circle does not exhaust what it is for that object to be circular nor even describe the most important feature of being circular. Yet that, I think, is the point. Secondary qualities are defined merely as the power to produce ideas in us, whereas primary qualities are not merely powers to produce ideas in us (though they do produce ideas in us).

Locke contrasts primary and secondary qualities in a variety of ways, but one important contrast is that primary qualities are "inseparable" from objects in a way that secondary qualities are not. If we divide a grain of wheat, and then divide it again, and so on until the grain of wheat is imperceptibly small, the divided pieces of wheat "must retain still each of them all those [primary] qualities" (II.viii.9, 134- 35). Theimperceptibly small grains of wheat still have the defining characteristic of the primary qualities and thus still have those properties. So, primary qualities are not defined by their ability to cause sensations in us (though they do cause sensations in us). Primary qualities are powers, but they are not merely powers. By contrast, secondary qualities are defined as "Powers to produce various Sensations in us" (II.viii.10, 135). The imperceptibly small wheat does not appear any color to us, and thus does not have any color. In this way secondary powers

${ }^{12}$ Bennett, Locke, Berkeley, Hume, 94; Lowe, Locke on Human Understanding, 50.

${ }^{13}$ J . L. Mackie, Problems from Locke (Oxford: Clarendon Press, 1976), 11- 12; Rickless, "Primary and Secondary Qualities,” 301- 2; Stuart, “Locke’s Colors,” 70. 
are merely powers. So, even though Locke sees primary and secondary qualities both as powers, there is still a metaphysically important distinction between them.

The categorical-dispositional property distinction gives us a way to understand Locke's primary-secondary quality distinction. Most of the primary qualities are paradigm examples of categorical properties, and even solidity might be thought of as a categorical property. By contrast, secondary qualities appear to be dispositional properties to cause sensations in us. This is the traditional way to interpret Locke, and the interpretation that I am defending here. However, there have been some challenges to this interpretation, to which I now turn.

\section{Against the Dispositionalist View}

Some interpreters claim that for Locke an object has a color (and other secondary qualities) only while it is being perceived. There are two considerations supporting this contention. First, at several points Locke seems to deny that objects have colors (or other secondary qualities) while they are not being perceived. Second, there is reason to believe that Locke does not privilege any one color as the color of the object, which would cut against the Dispositionalist View since on this kind of view colors are typically identified as the color an object would appear under standard conditions. I will take up each of these objections to the Dispositionalist View in turn.

The primary reason to doubt that Locke holds the Dispositionalist View is that he seems to say that objects do not have color in the dark:

Let us consider the red and white colours in Porphyre: Hinder light but from striking on it, and its Colours Vanish; it no longer produces any such Ideas in us: Upon the return of Light, it produces these appearances on us again. Can any one think any real alterations are made in the Porphyre, by the presence or absence of Light; and that those Ideas of whiteness and redness, are really in Porphyre in the light, when 'tis plain it has no colour in the dark? It has, indeed, such a Configuration of Particles, both Night and Day, as are apt by the Rays of Light rebounding from some parts of that hard Stone, to produce in us the Idea of redness, and from others the Idea of whiteness: But whiteness or redness are not in it at any time, but such a texture, that hath the power to produce such a sensation in us. (II.viii.19, 139)

Locke says here that porphyry "has no colour in the dark" and says that when we turn off the lights "its Colours Vanish." Matthew Stuart argues that this passage shows that secondary qualities are not dispositions. For, he argues, if colors were dispositions, then "he should be saying that objects retain their colors in the dark." ${ }^{14}$ But, according to

14 Stuart, “Locke’s Colors,” 68. 
Stuart, Locke denies this. So, when Locke says porphyry does not have color in the dark, this seems to show that, for Locke, color is not a dispositional property. ${ }^{15}$

Although Edwin Curley and E. J . Lowe interpret Locke as holding the Dispositionalist View, they concede that the porphyry passage and other similar comments are inconsistent with Locke's considered view. Curley says, "the view that objects do not have colors in the dark and the more general view that they would not have any secondary qualities in a world lacking perceivers are examples of those unfortunate inconsistencies for which Locke's work is so famous." 16 Speaking of Locke's commitment to the Dispositionalist View, Lowe says he "does not always follow through with its implications," and that he is "ambivalent" about "whether the mere possession of these powers warrants ascriptions of colour to the objects possessing them, or whether we should say that the objects are 'really' colored . . . only when those powers are actually being manifested."17

It is not obvious, though, that Locke is saying that the porphyry ceases to have the secondary quality of color when the lights are turned off, which quality would return if we turn the lights back on. On an alternative interpretation, Locke is making the relatively weak claim that an object does not manifest its color in the dark. Although he says, "Hinder light but from striking on it, and its Colours Vanish," he then immediately adds, "it no longer produces any such Ideas in us: Upon the return of Light, it produces these appearances on us again" (II.viii.19, 139; my emphasis). The phrase "its Colours Vanish" is glossed by Locke as no longer causing the sensation of color in us. The point then seems to be that objects do not cause us to have sensations of color in the dark. In the next supposedly damning comment, Locke says, "Can any one think . . . that those Ideas of whiteness and redness are really in Porphyre in the light, when it is plain it has no colour in the dark?" Locke does here assert that the porphyry has no color in the dark, but again this is glossed as not causing the sensation of red and white in us. ${ }^{18}$ It is consistent with the Dispositionalist View that an object has a disposition to cause in us the sensation of red even when the object is not currently doing so. Thus, Locke can be interpreted as making a relatively weak claim that the color of porphyry is not manifest in the dark.

15 Stuart, "Locke's Colors," 68. See also Rickless, "Primary and Secondary Qualities," 313; Pasnau, Metaphysical Themes, 534.

${ }^{16}$ Curley, "Primary and Secondary Qualities," 440.

${ }^{17}$ Lowe, Locke on Human Understanding, 52- 53.

${ }^{18}$ Here Locke does imply the further claim that the idea of color is not "really in" the porphyry. But color is never "really in" an object, so if this comment were taken as evidence that porphyry lacks color in the dark then objects would always lack color. This is clearly mistaken. Consequently, an object can have a secondary quality while at the same time not being "really in" the object. (Lisa Downing, "Locke: The Primary and Secondary Quality Distinction," in The Routledge Companion to Metaphysics, ed. Robin Le Poidevin, et al [New York: Routledge, 2009], 98-99) I take the point here to be that the idea of a color does not resemble a property in the material object (see discussion below). 
Samuel Rickless argues that Locke's use of the terms "idea" and "quality" suggests that he denies that the porphyry has color in the dark: "Locke himself admits to using the word 'idea' to mean the same as 'quality' when speaking of ideas being in bodies (2.8.8), and this is case in point. When Locke suggests that the 'ideas' of whiteness and redness are not really in porphyry, he surely means that the qualities of whiteness and redness are not really in porphyry." 19 This is not convincing. In the porphyry passage the term "idea" plainly refers to the sensation of color, as evidenced by the fact that, when the lights are on, the idea of red is produced "in us" (II.viii.19, 139); Locke does not assert, neither here nor anywhere else, that the secondary quality of color is produced in the object when the lights are turned on. So, we can reasonably interpret Locke as making the rather modest claim that an object does not cause sensations of color in the dark.

Rickless objects to this sort of interpretation, insisting that the point of the passage is that secondary qualities are mind-dependent and so do not exist in an object when not being perceived. However, the claim that the porphyry does not have a color in the dark is an "essential premise" of the argument Locke is supposedly making. ${ }^{20}$ But I deny that Locke even accepts this "essential premise," much less makes use of it as an essential premise of the argument in this passage. Locke seems to be making a rather different point. He uses the porphyry case to show that the way red appears to me (i.e., my idea of red) is not a property in the porphyry; that is, the idea of red does not resemble a property in the porphyry. ${ }^{21}$ When Locke asserts that secondary qualities are not "really in" a material object, I take him to be claiming that "There is nothing like our Ideas [of secondary qualities], existing in the Bodies themselves" (II.viii.15, 137; my emphasis). Rickless argues against this interpretation because when Locke denies that porphyry has color in the dark (II.viii.19) he does not say anything about resemblance. ${ }^{22}$ However, II.viii.15- 22 are titled "Ideas of primary Qualities are resemblances; of secondary, not." Presumably, then, the aim in II.viii.19 is to support the point that secondary qualities do not resemble qualities in material objects. This point is easily accommodated by the Dispositionalist View, since II.viii.19 can be understood as arguing that the manifestation of the porphyry's color is not identical to, and so does not resemble, the dispositional properties in the porphyry that cause us to have the sensation of that color.

Despite initial appearances, the porphyry passage does not actually provide very good evidence that Locke rejects the Dispositionalist View. There is a reasonable interpretation available which render Locke's comments consistent with his apparent commitment to the view that secondary qualities are dispositional properties.

${ }^{19}$ Rickless, “Primary and Secondary Qualities,” 314- 15.

20 Rickless, "Primary and Secondary Qualities," 313.

${ }^{21}$ Keith Allen, "Mechanism, Resemblance, and Secondary Qualities: From Descartes to Locke," British Journal for the History of Philosophy 16, no. 2 (2008): 279, https:// www.doi.org/ 10.1080 109608780801969092; and Downing, “Locke: Primary and Secondary Quality Distinction,” 107.

22 Rickless, “Primary and Secondary Qualities,” 314. 
Stuart also uses a second line of argument against the Dispositionalist View. He takes perceptual variability, along with Locke's claims to veridical sensation, to be another source of evidence against the Dispositionalist View. Stuart points out that it is possible for one object to be causing two different color experiences in two different people simultaneously. A theorist is thereby presented with a choice: either privilege one color as the "real" color of the object or allow that the object is two different colors. ${ }^{23}$ The Dispositionalist View takes the one "real" color of an object to be how it appears "in normal observers under standard conditions." 24 Snow is white, for example, because snow has the disposition to appear white to a normal observe in broad daylight. Even when the sun sets and the snow appears pink, the snow is white because even at sunset the snow retains the disposition to produce in us the sensation of white under standard conditions. If the object has only one "real" color, then the second color must be a merely apparent color. Stuart, however, argues that on Locke's view there are no merely apparent colors, and thus this is evidence that Locke does not hold the Dispositionalist View.

Stuart argues that all sensations of color count as genuine colors for Locke and hence that he denies the possibility of merely apparent colors. Real ideas "have a Conformity with the real Being, and Existence of Things, or with their Archetypes" (II.xxx.2, 372- 73). Locke says, "Our simple Ideas are all real, all agree to the reality of things," and Locke cites the idea of white as a simple and therefore real idea (II.xxx.2, 372; see also IV.iv.4, 563-64). Stuart argues: "It seems reasonable to presume that a color idea perfectly represents its archetype, and conforms to the real existence of things, only when it presents something as being a color it is. If all of the color ideas produced in us do this, then there are no merely apparent colors." 25 During the day the snow causes me to have the sensation of white, whereas in the evening the snow causes me to have the sensation of pink. Since both these ideas are real, and both these ideas accurately represent the same object, the snow must actually be two different colors.

Contrary to Stuart's claim, though, Locke does seem to privilege one color as the color of the object. Presumably Locke recognizes that snow can appear different colors. (Stuart accepts this, at any rate.) Yet Locke nonetheless makes white one of the defining qualities of snow, or (to use Locke's term) part of its nominal essence (II.viii.8, 134; II.viii.16, 137; II.xxx.2, 372- 73). Even if snow can appear pink, its ability to appear white is what makes us call it "snow". So, Locke seems to be identifying the color of snow as how it appears to normal perceivers in standard conditions. Further, Locke thinks it would be an abuse of language to call snow "black" since doing so would "put Black, which is a Word agreed on to stand for sensible Idea, [and] to put it . . . for another, or the contrary Idea" (III.x.11, 496). The assumption here is that our idea of snow includes the color white, and so, if someone said that snow was the color black, then they would be using the term "black" to refer to the idea of white, which is an abuse of language. Thus, Locke seems to be

\footnotetext{
${ }^{23}$ Stuart, “Locke’s Colors,” 76.

${ }^{24}$ See J ohnston, "How to Speak of Colors," 230; Stuart, “Locke's Colors," 76.

25 Stuart, “Locke’s Colors,” 76; my emphasis.
} 
privileging white as the color of snow. Elsewhere, Locke says of gold, yellow is a "Power in Gold, to produce that Idea in us by our eyes, when placed in due light" (II.xxiii.10, 301; my emphasis). It is because gold appears yellow to us in normal light that we say gold is yellow. Again, then, Locke seems to think that an object's color is determined by how it appears to normal perceivers in standard conditions.

This leads us to perhaps the most incisive criticism of the view that colors exist in the objects only while they are being perceived. For Locke, an object is gold if and only if it conforms to the nominal essences of gold, which is to say that the object has the defining qualities of gold. Locke says that it is the "Colour, Weight, Fusibility, and Fixedness, etc. which makes it to be Gold, or gives it a right to that Name" and "nothing can be call'd Gold, but what has a Conformity [to these] Qualities" (III.iii.18, 419; my emphasis). Elsewhere he says, "the nominal Essence of Gold, is that complex Idea the word Gold stands for, let it be, for instance, a Body yellow, of a certain weight, malleable, fusible, and fixed" (III.vi.2, 439; my emphasis). From these and other passages we can see that the color yellow is a defining quality of gold. So, if an object is not yellow, then it is not gold. Yet, on Stuart's interpretation, no object is yellow when it is not being perceived. If we observe a gold ring then, while we observe it, it is gold; but once we turn off the light or put it in the drawer the ring is no longer yellow and so no longer gold. (Apparently there is no gold in Fort Knox!) That is absurd, and we ought to be reluctant to attribute such a position to Locke. ${ }^{26}$

Stuart recognizes this "potentially worrisome implication," but he "den[ies] that it is a problem." He argues that because "Locke says repeatedly that ideas of colors are constituents of nominal essences, and he says that objects lose their colors when they are in the dark and when they are causally isolated. So it should hardly count against an interpretation of Locke that it commits him to the view that some objects cease to fall under some nominal essences when these objects are in the dark or are off by themselves unobserved."27 Stuart's argument might be stated in the following way:

P1 All gold is yellow. [The nominal essence of gold]

P2 X (which is gold in the light) is not yellow in the dark. [Stuart's interpretation]

C So, $\mathrm{X}$ is not gold in the dark.

Stuart thinks that Locke commits himself to P1 and P2, and these together imply that X is not gold in the dark, and so this implication should not count against his interpretation.

However, Stuart is using the claim at issue in order to defend an outrageous implication of his interpretation. The Dispositionalist View denies P2 and can consequently avoid the implausible conclusion that a gold ring ceases to be gold when the lights are turned off. So, if Stuart asserts the controversial P2, and this entails an

${ }^{26}$ See also Downing, “Locke: Primary and Secondary Quality Distinction,” 107.

27 Stuart, “Locke’s Colors,” 81. 
implausible consequence, then (contrary to what Stuart claims) this should count as evidence against his interpretation. Further, we can flip Stuart's argument around and use it as evidence against the view that objects have color only while they are being perceived. If we start with the intuitively plausible claim a gold ring remains gold in the dark, then we get the following argument against Stuart's interpretation:

P1 All gold is yellow. [The nominal essence of gold]

$\mathrm{P} 2 * \mathrm{X}$ (which is gold in the light) is gold in the dark. [The Dispositionalist View]

$\mathrm{C}^{*}$ So, $\mathrm{X}$ is yellow in the dark.

P2* is intuitively true, Locke never denies it, and the conclusion of the argument is an acceptable one. Therefore, the Dispositionalist View, which accepts P2*, is preferable to Stuart's controversial interpretation, which leads to an implausible account of secondary qualities.

The two criticisms of the Dispositionalist View we have considered, then, are unpersuasive. Although Locke does seem to deny that objects have colors in the dark, these passages can also be interpreted to mean that an object's colors are not manifest in the dark. Since an object can retain a dispositional property when it is not manifest, and the manifestation of the secondary quality of color is a certain kind of sensation, Locke can consistently (and plausibly) hold that secondary qualities are dispositional properties. And even though all simple ideas are real ideas, it does not follow that objects have no privileged color. Locke sometimes takes the color that an object would appear under to normal observers in standard conditions to be part of its nominal essence, and in this way privileges that color over other ways the object may appear. Thus, the Dispositionalist View can adequately respond to recent criticisms of that interpretation. In the next section, I give positive arguments to the conclusion that the Dispositionalist View is the best way to understand Locke's position.

\section{For the Dispositionalist View}

The main reason for attributing the Dispositionalist View to Locke is that he defines secondary qualities as the power to produce certain sensations in us, and even though objects have these qualities while they are not being perceived, they manifest these qualities only under certain conditions. In this section my aim is to establish the claim that, according to Locke, objects retain their secondary qualities when they are not being perceived.

Secondary qualities "are nothing in the Objects themselves, but Powers to produce various Sensations in us by their primary Qualities, i.e., by the Bulk, Figure, Texture, and Motion of their insensible parts" (II.viii.10, 135). Locke does not identify color as the actualization of this power (appearing red is not identical to the secondary quality red); rather, the secondary quality is identified as the power to make an object appear red. Although Locke sometimes says the sensation of red depends on the lights being on, in the same breath he insists that the power to produce this sensation remains in the object. 
Consider again the porphyry passage (II.viii.19, 139). Locke asserts that the porphyry has "such a Configuration of Particles, both Night and Day, as are apt . . to produce in us the Idea of redness." Even in the dark, porphyry is "apt" to cause in us the idea of redness. This can easily be interpreted as the claim that the porphyry retains the disposition to cause in us the sensation of red even in the dark. Further, Locke identifies this disposition as a power: the "texture [of the porphyry] ... hath the power to produce such a sensation in us" (II.viii.19, 139; my emphasis). The porphyry has the power to produce in us the sensation of red, even in the dark, and the secondary quality red just is the power to produce in us that sensation. Therefore, the porphyry retains its secondary qualities such as color even when it is not currently being perceived.

Stuart and Pasnau both argue that for Locke an object has the power to produce the sensation of secondary qualities only while producing the sensation of secondary qualities. ${ }^{28}$ However, there is good evidence that Locke holds that an object has powers even when they are not being exercised. Consider, for example, the nominal essence of gold: "Thus when we pronounce concerning Gold, that it is fixed, our Knowledge of this Truth amounts to no more but this, that fixedness, or a power to remain in the Fire unconsumed, is an Idea, that always accompanies, and is join'd with that particular sort of Yellowness, Weight, Fusibility, Malleableness, and Solubility in Aqua Regia, which make our complex Idea, signified by the word Gold" (IV.i.6, 527). Locke indicates that "fixedness" is "a power to remain in the fire unconsumed." Presumably "Fusibility, Malleableness, and Solubility in Aqua Regia" are also powers. In order for an object to be called gold, it must have all of these powers. Notice, though, that no one object can manifest all of these powers at the sametime. Gold can manifest its malleability only while it is solid, whereas gold can manifest its fixedness only while it is a liquid. On the deflationary sense of "power" Stuart and Pasnau attribute to Locke, an object can have the power only while it is manifest. But then it would be impossible for any object to be gold, since being gold requires that an object be both fixed and malleable. But Locke thinks that we can know that the same object is both fixed and malleable (IV.xii.9, 64445). So, contrary to Stuart and Pasnau, Locke seems to think that objects can retain their powers even when those powers are not being manifest.

Elsewhere, Locke implies that an object retains the power to produce certain sensations when they are not being perceived, and these powers are secondary qualities: "Take away the Sensation of [secondary qualities]; let not the Eyes see Light, or Colours, nor the Ears hear Sounds; let the Palate not Taste, nor the Nose Smell, and all Colours, Tastes, Odors, and Sounds, as they are such particular Ideas, vanish and cease, and are reduced to their Causes, i.e. Bulk, Figure, and Motion of Parts" (II.viii.17, 138; my emphasis). Here Locke specifies exactly in what sense secondary qualities "vanish and cease" when they are not being perceived: "as they are such particular Ideas;" that is, the manifestations of those properties are not present when the object is not being perceived. Yet there is still a sense in which the object retains secondary qualities; namely, they are "reduced to their Causes." The primary qualities, which ultimately cause the perception

28 Stuart, “Locke's Colors,” 76; Pasnau, Metaphysical Themes, 534. 
of secondary qualities, remain in the object when it is not being perceived. So, it retains the causal power to produce the sensation of secondary qualities even when it is not being perceived.

Indeed, secondary qualities seem to be reducible to an arrangement of primary qualities and therefore, so long as those primary qualities remain the same, the secondary qualities remain in the object even when they are not being perceived. Locke defines secondary qualities as "Powers to produce various Sensations in us by their primary Qualities" (II.viii.10, 135) and says that when an object is not currently being observed its secondary qualities are "reduced to their Causes, i.e. Bulk, Figure, and Motion of Parts" (II.viii.17, 138). The disposition to cause a certain sensation in us is reducible to some arrangement of primary qualities, most relevantly the texture of an object's surface. With this in mind, again consider the porphyry passage. He asks, "Can any one think any real alteration is made in the Porphyre, by the presence or absence of the Light... ?" No, there is no real change; the primary qualities, including "such a texture, that hath the power to produce such a sensation [of red] in us", remains in the object the whole time (II.viii.19, 139). Thus, the secondary quality, which is reducible to that arrangement of primary qualities, remains in the object even when it is not being perceived.

Indeed, Locke's account of real essences entails that objects retain their secondary qualities while not being perceived. Locke indicates that the properties of an object, including its color, are determined by its real essence. The real essence of an object is its fundamental properties: the other non-accidental properties of an object "depend" on its real essence and "flow" from its real essence (II.xxxi.6, 378- 80; III.iii.18, 418- 19; etc.). Elsewhere I have argued that Locke's position is best characterized as a form of essentialism. ${ }^{29}$ Essentialism is the view that all the non-accidental properties and behavior of an object follow logically from its real essence. Hence, Locke asserts that if we knew what the real essence of gold was, then we could (at least in principle) deduce all the properties of gold from its real essence (IV.vi.11, 585- 87; IV.iii.25, 555- 56). Importantly for our purposes, Locke lists color as a property that follows from the real essence of gold (II.xxxi.6, 378- 80; III.iii.18, 418- 19). On the essentialist interpretation, then, the color of (at least some) objects follows necessarily from its real essence. In that case, since no real change occurs to the object when we when the light is turned on and off, the object retains its color even when it is not being perceived.

Even if an essentialist interpretation of Locke is rejected, ${ }^{30}$ Locke's account of real essence supports the view that an object retains its secondary qualities when not being perceived. On an alternative, voluntarist interpretation, Locke thinks that God arbitrarily determines the relationship between the real essence of an object and its properties (IV.iii28-29, 559-60). Perhaps this is so. Still, Locke asserts there is a connection between the real essence of an object and its other properties. Perhaps this connection is imposed by God (as Stuart holds) or perhaps the connection is due to the nature of the

${ }^{29}$ Nathan Rockwood, "Lockean Essentialism and the Possibility of Miracles," Southern Journal of Philosophy 56, no. 2 (J une 2018): 293-310.

30 Stuart, Locke's Metaphysics. 162- 73. 
real essence of an object (as I argue for elsewhere). Either way, there is a one-to-one correlation between a given real essence and a set of secondary qualities. So long as the real essence remains the same, then, the object will have the same secondary qualities.

On my interpretation, the real essence of macroscopic objects entails that color is a necessary and inseparable property of that object. Locke says as much, arguing that there are unknown "properties in gold, all of them as inseparable from its internal constitution as its colour and weight" (II.xxxi.10, 382; my emphasis). However, this seems to conflict with two claims he makes elsewhere: first, Locke thinks some objects do not have a color and, second, secondary qualities are mind-dependent, and so, if there were no perceivers, objects would not have secondary qualities. If so, then it appears color is not a necessary property of objects.

First consider objects without color. Locke introduces primary qualities by identifying them as those qualities imperceptibly small particles would have. He concludes that primary qualities are "inseparable from body" (II.viii.9, 134). By implication, these imperceptibly small particles do not have secondary qualities; consequently, secondary qualities are separable from body. It might be objected, then, that my interpretation makes color a necessary property of body whereas Locke denies this. ${ }^{31}$ Also, diamonds and, under a microscope, blood appear to be colorless (II.xxiii.11, 301-2).32 It might be objected, then, that color is separable from objects and therefore not a necessary property. My reply is simply to concede that color is not a necessary property of body as such. Imperceptibly small particles do not have color and some macroscopic objects appear to be colorless. However, in at least some cases, the real essence entails that a macroscopic object has a certain color, and for such an object its color is a necessary property.

Next consider Locke's claim that objects would not have secondary qualities if there were no one to perceive them: "Since were there no fit organs to receive the impressions fire makes on the sight and touch; nor a mind joined to those organs to receive the ideas of light and heat, by those impressions of the fire, or the sun, there would yet be no more light or heat in the world than there would be pain if there were no sensible creature to feel it, though the sun should continue just as it is now, and Mount Aetna flame higher than ever it did" (II.xxxi.2, 376). It is obvious that there would be no pain in the world if there were no minds that felt pain. Likewise, Locke suggests, there would be no light or heat. This passage has been used to argue that the secondary qualities of macroscopic objects are dependent on there being observers. ${ }^{33}$ If this is right then, secondary qualities would be separable from macroscopic material objects, and we may therefore have reason to deny that objects retain their secondary qualities while they are not being perceived.

However, in the preceding sentences Locke clarifies what he means when he says that there would be no light or heat without anyone to observe these qualities:

${ }^{31}$ Rickless, "Primary and Secondary Qualities,” 303.

32 See also Allen, “Mechanism, Resemblance, and Secondary Qualities,” 280.

33 Rickless, “Primary and Secondary Qualities,” 305- 6. 
For though Fire be call'd painful to the Touch, whereby is signified the power of producing in us the Idea of Pain; yet it is denominated also Light, and Hot; as if Light and Heat, were really something in the Fire, more than a power to excite these Ideas in us; and therefore are called Qualities in, or of the Fire. But these being nothing, in truth, but powers to excite such Ideas in us, I must, in that sense, be understood, when I speak of secondary Qualities, as being in Things; or of their Ideas, as being in the Objects, that excite them in us. (II.xxxi.2, 375; my emphasis)

Locke objects to the claim that the qualities of light and heat are "really . . . in the Fire" as "more than a power to excite these ideas in us:" for "in truth" light and heat are "but powers to excite such Ideas in us," and that is how Locke wishes "to be understood, when I speak of secondary qualities as being in things." On this view, secondary qualities exist in objects as powers and nothing more than powers. This is confirmed elsewhere, when Locke says that absent any observers the secondary qualities of objects "are reduced to their Causes" (II.viii.17, 138) and "are nothing in the Objects themselves, but Powers" (II.viii.10, 135; II.xxiii.10, 301). So, Locke's point in saying that, absent any observers, secondary qualities are not in the object is that secondary qualities exist in objects only as powers. Importantly, though, the powers do exist in the objects, including when they are not being perceived.

The above considerations provide strong reasons for interpreting Locke as holding the Dispositionalist View of secondary qualities. A secondary quality is a power in an object to produce certain sensations in us, and for Locke, an object retains this power even when it is not currently producing in us that sensation. Further, secondary qualities are defined by the sensations they cause in us. Thus, as with dispositional properties, the defining characteristic of secondary qualities are manifest only under certain conditions. This seems to make secondary qualities dispositions to cause sensations in us. Moreover, the criticisms of this interpretation of Locke are not persuasive. I conclude, then, that Locke does indeed hold that secondary qualities are dispositional properties. ${ }^{34}$

Brigham Young University

${ }^{34}$ I thank Lisa Downing, Greg Novack, Tristram McPherson, Samuel Rickless, Kelly Trogdon, and the anonymous reviewers of this journal for their helpful feedback on earlier drafts of this paper. 


\section{Bibliography}

Allen, Keith. "Mechanism, Resemblance, and Secondary Qualities." British J ournal for the History of Philosophy 16, no. 2 (2008): 273-91. https:// www.doi.org/ 10.1080 $\angle 09608780801969092$

Bennett, J onathan. Locke, Berkeley, Hume: Central Themes. Oxford: Clarendon Press, 1971.

Curley, Edwin M. "Locke, Boyle, and the Distinction between Primary and Secondary Qualities." The Philosophical Review 81, no. 4 (October 1972): 438- 64. https:// www .doi.org/ 10.2307/2183887.

Downing, Lisa. "Locke: The Primary and Secondary Quality Distinction.” The Routledge Companion to Metaphysics. Edited by Robin Le Poidevin, Peter Simons, Andrew McGonigal, and Ross P. Cameron, 98- 108. New York: Routledge, 2009.

Johnston, Mark. "How to Speak of the Colors." Philosophical Studies: An International J ournal for Philosophy in the Analytic Tradition 68, no. 3 (December 1992): 221- 63.

Locke, J ohn. An Essay concerning Human Understanding. Edited by Peter H. Nidditch. The Clarendon Edition of the Works of J ohn Locke. Oxford: Clarendon Press, 1975.

Lowe, E. J. Locke on Human Understanding. Routledge Philosophy Guidebooks. New York: Routledge, 1995.

Mumford, Stephen. Dispositions. Revised edition. Oxford: Oxford University Press, 2003.

Mackie, J . L. Problems from Locke. Oxford: Clarendon Press, 1976.

Pasnau, Robert. Metaphysical Themes, 1274- 1671. Oxford: Clarendon Press, 2011.

Stuart, Matthew. “Locke's Colors,” The Philosophical Review 112, no. 1 (J anuary 2003): 57- 96.

—. Locke’s Metaphysics. Oxford: Clarendon Press, 2013.

Rickless, Samuel C. “Locke on Primary and Secondary Qualities” Pacific Philosophical Quarterly 78, no. 3 (September 1997): 297- 319.

Rockwood, Nathan. "Lockean Essentialism and the Possibility of Miracles." Southern J ournal of Philosophy 56, no. 2 (J une 2018): 293- 310. 